\title{
The impact of the COVID-19 pandemic on the shopping behaviour of customers of selected global brand marketing strategy
}

\author{
David Vrtana ${ }^{1, *}$ \\ ${ }^{1}$ University of Zilina, Faculty of Operation and Economics of Transport and Communications, \\ Univerzitna 1, 01026 Zilina, Slovakia
}

\begin{abstract}
Research background: Research will highlight the impact of the COVID19 pandemic on Mc Donald's brand marketing strategy. In the research, we will analyze the internal and external environment of the global brand. We will find out how the current pandemic situation has affected the customer shopping behavior of the global brand Mc Donald's.

Purpose of the article: In this article, we point out the importance of analyzing customers' shopping behavior before and during a pandemic. We identify differences in shopping behavior before and during a pandemic. We will confirm whether our research identifies differences in the behavioral characteristics of the global brand's shopping behavior in terms of differences and penetration.

Methods: We used the methods of analysis, synthesis, comparison and generalization to assess the theoretical assumptions of purchasing behavior and marketing strategy. By comparison and generalization, we compare the financial performance of the brand during the COVID-19 pandemic. We will evaluate its significance in relation to shopping behavior. We will also use an analysis of the internal and external environment to identify the right marketing strategy for the global Mc Donald's brand. Subsequently, we compare the results and identify the possibilities of adapting the marketing strategy with respect to purchasing behavior before and during the COVID19 pandemic.

Findings \& Value added: We will point out the importance of the shopping behavior of Mc Donald's global brand customers before and during the pandemic. We will find out how customers' shopping behavior has changed and we will identify this change to the marketing strategy.
\end{abstract}

Keywords: marketing strategy; consumer behavior; global brand; consumer

JEL Classification: $M 30 ; M 31 ; M 37$

${ }^{*}$ Corresponding author: david.vrtana@fpedas.uniza.sk 


\section{Introduction}

At the turn of 2019 and 2020, a pandemic caused by COVID - 19 gradually began to enter the world. This pandemic in many ways affected the strategies of international companies, which had to change their internal and external processes to cover increased costs. Not only production, innovation, but also sales - marketing strategies were influenced in many ways and had to adapt to current changes. Customers' shopping behavior changed during the pandemic, and we can say that it no longer respected the traditional communication mix. The communication mix began to come to the fore, accepting new elements as an online environment, in which, according to Scott et al. (2020) intelligent services, communication with customers. Another innovative feature that has come to the forefront are products that meet customer needs right at home (Scott et al., 2020). In connection with the new elements applied in purchasing behavior, the authors of Musova et al. (2021) argued that higher environmental responsibility could also be a new element, which should be an integral part of the company's marketing strategy. The authors' statement can be accepted as greater environmental responsibility with regard to the COVID - 19 pandemic is also particularly represented for global brands and shopping behavior in general. The authors claim that such responsibility to a large extent also influences other purchasing decisions, which form a substantial part of customers' market behavior.

According to the authors of Valaskova et al. (2021) The COVID-19 pandemic has caused changes in consumers' shopping behavior in the form of shopping habits. According to the results of the research, the authors found that the income, age and employment of the consumer play an important role in the context of new shopping models (Valaskova et al., 2021). We can only partially agree with the authors' statements because they are defined as key, but other factors also play an important role, such as the customer's relationship to the brand, the influence of emotions and emotional behavior, social and cultural factors and the like. The aim of the article is to point out the importance and change of consumer shopping behavior during the COVID-19 pandemic at the global brand McDonald's, which also has a significant presence in the market environment of the Slovak Republic. In this article, we analyzed internal and external factors that are important in influencing customers' shopping behavior during the COVID-19 pandemic and significantly complete the overall marketing strategy. Part of the analysis of the market environment is the analysis of trends and procedures in connection with the adjustment of current strategies and evaluation of the current financial performance of the company with regard to the current pandemic situation of COVID-19.

\section{The importance of the McDonald's brand in the current market environment}

The importance of a company in a market environment is determined by various factors such as the application of elements of communication strategy, customer care, pricing or distribution policy. McDonald's Corporation, which has been operating in the market environment since 1940 , is also such a company.

The main activity of McDonald's Corporation is the operation of fast-food restaurants. At present, in addition to the production and sale of food, beverages, their distribution, promotional activities, the provision of economic advice, the company is also engaged in distribution activities or the organization of various social and cultural events. We can include the organization of social and cultural events in the area of social responsibility, especially when organizing events with a charitable mission. Such corporate social responsibility is perceived at the global level and works equally for different countries. (McDonald's Mission, Vision and Values, 2021) 
The mission of the McDonald's brand is to create a favorite place and way of eating for various customer segmentation structures. By offering quality food at affordable prices, the brand strives to satisfy basic human needs. With regard to the international environment, the company emphasizes the creation of a popular place where customers can socialize. To achieve this mission, the company must constantly renew the interest of the target group. McDonald's strives to do this by offering new products, promoting and creating innovative ways to meet customer needs (Abiodun, 2010).

In view of the opportunities and threats in the global world, it is necessary for the brand to constantly adapt to the changing market environment. The global pandemic, which has been going on since 2020, also has a significant impact on the introduction of innovative elements of the McDonald's brand. The application of new innovative elements contributes to the greater sustainability of existing customers, but also to the acquisition of new ones. In the current market environment, we can perceive various innovations that the brand applies in the market environment. It can be, for example, shortening the time of order preparation, new products offered to customers, distribution of the order directly to the customer's home, expansion of a geographically distributed network of restaurants, introduction of self-service kiosks, mobile application (Warc, 2020). If a company adds brand promotion to these services, it can generate interest in new customers.

Adapting to current trends in the context of the global pandemic has been crucial for the company. In the first quarter of 2019, worldwide comparable sales increased by $7.5 \%$ and total revenue for the period was $\$ 5.2$ billion with operating income of $\$ 2.3$ billion. The brand recorded the highest sales in the markets of the USA, Great Britain, Australia and Canada. European countries underperformed during this period. In Spain, where tourism is dominant, an average year-on-year decrease in sales of 5.2\% was recorded. The costs in each country varied depending on the current pandemic situation and the measures taken by the countries. As of March 31, 2020, the company recorded a comparable year-on-year decrease in sales by $3.4 \%$. In connection with the constantly changing market environment, the brand also had to change marketing strategies at the company-wide global level as a matter of priority. In 2021, the company expects global revenue to be comparable to 2019. By 2022, the company wants to spend approximately $\$ 2.3$ billion on capital expenditures (Warc, 2020). Of this amount, part of the dollars will be used to build new facilities and the other part will be used to rebuild existing restaurants (Valentine, 2021).

\subsection{Formatting the title, authors and affiliations}

At the beginning of the article, we wrote that the COVID - 19 pandemic caused a significant change in purchasing behavior and decision - making. Due to various measures taken by states, customers were forced to move their behavior to an internal and, to some extent, limited, external environment. In this context, brands began to implement innovative strategies to maintain stability in the market environment and secure revenues at previous years' levels. The McDonald's brand also had to make such a change.

McDonald's global growth strategy was Accelerating the Arches. The strategy should be applied at the highest level. The main purpose of the strategic elements was simplicity and focus on customer needs. The company has introduced a narrow range of products in many countries. The narrowed offer was important due to faster services, shorter lines and higher margins. With this strategy, the company sought to maximize its marketing in a culturally relevant way. The company has further doubled the number of digital and delivery units to support speed and simplicity in meeting customer needs (Valentine, 2021). In this context, the author of Fleming (2020) stated that the aim of McDonald's new marketing strategy is to focus on a goal aimed at maximizing investment and customer loyalty. Focusing on customer loyalty during a global pandemic is an important element of a company's sustainability in a 
market environment. In this way, the basic concepts of the elements of the marketing mix change and adapt to the current market situation (Fleming, 2020).

The sustainability of existing customers is a challenging process and, as part of its growth strategy, the brand has focused on three D: drive markets; delivery and digital.

The core of McDonald's product portfolio are classic products such as Big Mac, Chicken McNuggets, which account for $70 \%$ of the company's total sales in developed markets. Based on the results of current marketing research, the company stated that these basic products will continue to be an important core of the company's product portfolio (Vrbka et al., 2019). Part of the growth strategy is to create a new product offering - "McPlant". The new menu is based on plants and cultiveless chicken farming. In 2019, McDonald's announced that $33 \%$ of chicken farms were cage-free. By 2025, the company wants to achieve $100 \%$ non-clique chicken farming. It is in connection with the creation of the new menu "McPlant" that the company works intensively with suppliers and farmers, the food company Cargill, which are to ensure the promotion of healthier food in McDonald's restaurants (Lintott, 2019). In 2021, the company also focused on basic products (eg coffee, chicken, burgers). As part of the new menu, "McPlant" introduced a crunchy chicken sandwich. It is this product that should support customer loyalty, attract new ones and contribute to the overall sustainability and stability of the company in the market environment (Kumar and Russ, 2020).

The digital area is also a part of the company's marketing strategy. During 2021 and 2022, the company is expected to launch the "MyMcDonald's" loyalty program via a mobile application. The loyalty program will allow customers to receive offers that reflect their physiological needs. Globally, the loyalty program will be launched in Phoenix and then in the United States (Kumar and Russ, 2020).

Another important area is the McDelivery service. According to statistics, up to $75 \%$ of the population in developed markets lives within $4.82 \mathrm{~km}$ ( 3 miles) of McDonald's. By introducing the service, the company is able to satisfy the basic physiological needs of customers at a higher level. These needs are met at a higher level of speed and comfort. In this way, the customer should be offered an experience when ordering products from the comfort of home. The customer can order products directly through the application, which is available and optimized in almost all markets. According to statistics, the success of the McDelivery service is at a high level. Over the past three years, the company has expanded the number of McDelivery restaurants to 28,000 restaurants worldwide in nearly 20 countries (McDonald's company, 2020).

\subsection{Financial performance of the brand during the first quarter of 2021}

Despite various limitations, the economic instability of the company's sales during the first quarter of 2021 is higher than during the same period in 2019. In the first quarter of 2021, the company recorded an increase in global sales of $7.5 \%$ compared to 2019 . This increase was comparable across all segments $-13.6 \%$ in the US and an increase of $06 \%$ in the International Operated and $6.4 \%$ in the International Developmental Licensed segment. Operating profit increased by $35 \%$ (a $30 \%$ increase in constant currencies), an increase of $\$$ 135 million. In the following table 1 we have shown a comparison of data according to the quarters of 2020 and 2021 (Macrotrends, 2021) 
Table 1. Comparison of financial performance in the first quarter of 2020 - 2021.

\begin{tabular}{|c|c|c|}
\hline Indicators & $\mathbf{2 0 2 1}$ & $\mathbf{2 0 2 0}$ \\
\hline U.S. & $13.6 \%$ & $0.1 \%$ \\
\hline International Operated Markets & $0.6 \%$ & $6.9 \%$ \\
\hline $\begin{array}{c}\text { International Developmental } \\
\text { Licensed Markets and Corporate }\end{array}$ & $6.4 \%$ & $4.3 \%$ \\
\hline Total & $7.5 \%$ & $3.4 \%$ \\
\hline
\end{tabular}

Source: McDonald's company (2021)

Based on the data in the table above, quarterly sales results are positive in all segments, despite the significant impact of the COVID - 19 pandemic since March. Customer numbers have remained negative in all segments examined.

International Operated Markets' positive results in the UK, Australia and Canada markets offset the markedly negative impact of the pandemic on the France and Germany markets. In other markets, the results declared restrictions on the part of governments. International Developmental Licensed Markets and Corporate results gradually improved throughout the quarter. The biggest development was recorded in the markets of China and Japan (Macrotrends, 2021).

In the following Table 2, we compared the financial performance within the consolidated indicators.

Table 2. Financial performance in consolidated indicators.

\begin{tabular}{|c|c|c|}
\hline Indicators & $\mathbf{2 0 2 1}$ & $\mathbf{2 0 2 0}$ \\
\hline Revenues & 5,124 dolars & 4,714 dol. \\
\hline Operatin income & $2,281 \mathrm{~d}$ & 1,693 \\
\hline Net income & 1,537 & 1,106 \\
\hline Earnings per share-diluted & 2,05 & 1,47 \\
\hline
\end{tabular}

Source: McDonald's company (2021)

Based on the data in the table, there is an increase in revenue in 2021 compared to 2020. Stronger operating performance in the US was due to higher margins for individual restaurants. The results for the quarter included 135 mil. Dollars (McDonald's company, 2021).

\subsection{Factors of the internal environment influencing the marketing strategy of the McDonald's brand}

In addition to external changes and adapting the growth strategy to customer behavior, the company also had to analyze elements of the internal environment. In response to the COVID - 19 pandemic, the company developed an agile model and team structure that supported integrated decision - making. Part of the team structure was a separate team COVID - 19, which was directly subordinate to the top management of the company. The team's main goal was to address rapidly changing information and evolving recommendations. The team structure also included a subgroup focused on the area of business, the aim of which was to improve the internal processes of restaurants as part of a rapid operational transformation. Another team focused on working with experts in the field of infection prevention and control (McDonald's company, 2021).

The change in conditions in the internal environment has also significantly affected the development of a new growth strategy that takes into account all the recommendations and conditions defined by the special teams. The internal environment for creating a marketing 
strategy is important. In this sense, we can see the cooperative interconnection, the result of which has a positive impact on the market position, financial performance and customer loyalty.

\subsection{Customer segmentation during the COVID-19 pandemic}

Based on the analysis of the internal and external environment of the brand, we came to various conclusions. They found that we company is effectively adapting to the domestic and international market due to the ongoing Covid-19 pandemic. It introduces a new marketing strategy, supports the development of digital and delivery services. The individual elements of the brand's marketing mix are enriched with elements that support the market stability and competitiveness of the company. Based on these elements, the segmentation structure changed during the Covid-19 pandemic.

Compared to the national market and the limited services market, the share of McDonald's relative visits was effective. The "healthy domestic masters" had the largest share of the segmentation structure, accounting for up to $19 \%$ of the segmentation. The so-called Urban influencers, whose share of visits reached $18 \%$. The social suburbs where the operations are located reached $11 \%$ attendance within the segmentation structure. Family visits during the pandemic were set at $6 \%$. Busy people reached $5 \%$ in the segmentation structure (Klein, 2020).

\section{Discussion}

As already mentioned in the introduction of the article, the COVID-19 pandemic caused a change in shopping behavior. According to Vrbek et al. (2019) considered the power of the economy. Therefore, it is necessary to adapt to this space in relation to customers (Vrbka et al., 2019).

By analyzing the internal and external environment, we identified the current state of the McDonald's brand in the market environment. Based on the information from the analytical part, we can say that the marketing strategy of the McDonald's brand was successful during the COVID-19 pandemic. The company created such internal and external conditions that enabled the effective implementation of elements of the new growth strategy and were able to effectively adapt to customer behavior.

The aim of the created marketing strategy was to demonstrate the company's values and its commitment to communities, customers, employees, farmers, fanatics and suppliers (Fleming, 2020). In relation to customers, the company presented a value that was of great importance for the current market environment. The purpose of the brand was in its strategy to focus on the environment, diversity, simplicity and satisfaction of basic living needs. For this reason, the support of communities and customer loyalty has also become the primary goal of the created strategy. It was during the COVID-19 pandemic that it was difficult to maintain customer loyalty due to economic instability, rising prices of goods and services, the introduction of government measures and the like. During this period, the brand had to adjust all processes to significantly support the sustainability of customer loyalty.

All the innovative ways that the brand introduced into the market environment were an important prerequisite for promoting loyal shopping behavior or gaining new customers. The changes that the brand has implemented can strengthen stability in the market environment, achieve profit and increase competitiveness.

Based on the results of the strategy, we can say that the marketing strategy of growth is perceived as part of a holistic concept, which focuses not only on the product portfolio, but also on how consumers order them. An important part of this strategy has become the McDelivery service with the support of digital services (eg mobile application). Gavurova et 
al. (2018) argue that supporting the development of digital services can strengthen customer loyalty to the brand (Gavurova et al., 2018). We agree with the authors' view (Knowitt, 2020) further argue that social media also have a significant impact on the application of digital services, which can support the customer's decision-making process. The developed strategy includes various elements by which the company wants to achieve the basic goal. Elements of this strategy can be seen as a way in which the brand seeks to create a customer experience in the emotional experience of product ordering, purchasing and delivery. This means that emotions that are a manifestation of the customer's experience can be an element of supporting customer loyalty to the brand (Ferencakova et al., 2020).

According to the analysis of the elements of the marketing strategy of growth, the goal of the company is to focus on communities, their support and help. Within the communities, the company focuses on five key areas, which are obtaining quality raw materials, protecting the environment, connecting with communities in developing countries and focusing on equality. As already written in subchapter 2.1, the aim of the company is to support agricultural communities (local farmers and producers). By improving environmental protection, the company wants to produce $100 \%$ recyclable packaging from renewable (recycled) sources by 2025 . In support of communities in need, the company donated quality food to developing countries in 2020 (Cision, 2020).

The promotion element was also part of the created marketing strategy. During the Covid19 pandemic, McDonald's created a series of commercials to highlight the change in life during the pandemic. The basic idea of the promotional campaign was to point out that the pandemic caused a change in life, but McDonald's still exists and offers the same products, at similar prices with sufficient security measures (Shastri, 2020). According to the authors of Worimegbe (2020), other elements (loyalty programs, advertising, gamification, etc.) are also an important part of the promotion area. These elements can be a positive tool to support customer loyalty to the brand (Worimegbe, 2020). Branding can be an important aspect of a customer's perception of product quality (see also Stefko et al., 2019; Stefko et al., 2020). The authors of Gregova et al. (2020) argue that the brand is a global trend influencing customers' shopping behavior. Gorska and Mazurek (2021) also agree with this view.

The individual elements of the marketing strategy can be considered innovative. By applying these elements, we can say that the financial performance of the company was stable. In evaluating financial performance, we took into account indicators that were comparable in the same period from 2019 to 2021 . Factors that significantly affected financial performance were economic instability and government measures. All these factors significantly influenced customers' shopping behavior. Due to these factors, financial performance was positive compared to 2019 and 2020 in 2021 (McDonald's company, 2021). The positive trend was caused by the development of strategic services in the international market environment, the development of digital services, the improvement of the product portfolio and the expansion of the international network of operations. All of these factors have significantly contributed to strengthening McDonald's overall marketing strategy. The authors of Bite and Konczos-Szombathelyi (2020) also agree with this opinion.

\section{Conclusion}

The McDonald's brand has a strong global position in the current market environment. Due to a strong growth strategy that includes various forms of offline and online marketing support from pricing policy to distribution, the brand has been able to maintain its leading position in a changing market environment. The brand has a significant impact on communities and communities that try to differentiate from standard ones through various promotional activities. Despite the global Covid-19 pandemic, which has caused economic instability in many countries, the McDonald's brand has managed to maintain a stable market 
position and a leading competitive position. It is important to emphasize that the immediate response to changes in the external and internal environment, the creation and application of a new marketing strategy, the development of digital services, significant customer orientation, understanding of their behavior and actions contributed to such a sustainable state.

\section{Acknowledgement}

This paper is an output of scientific project VEGA no. 1/0032/21: Marketing engineering as a progressive platform for optimizing managerial decision-making processes in the context of the current challenges of marketing management.

\section{References}

1. Abiodun, A. J. (2010). Interface between corporate vision, mission and production and operations management. Global Journal of Management and Business Research, 10(2), $18-22$.

2. Bite, P., \& Konczos-Szombathelyi, M. (2020). Employer branding concept for smalland medium-sized family firms. Journal of International Studies, 13(3), 143-160.

3. Cision. (2020, November 09). McDonald's Announces New Growth Strategy. Cision. Available at: https://www.prnewswire.com/news-releases/mcdonalds-announces-newgrowth-strategy-301168170.html

4. Claimed Company (2021, February 5). McDonald's Mission, Vision \& Values. The Comparably. Avaliable at: https://www.comparably.com/companies/mcdonalds /mission

5. Ferencakova, L., Gajdka, K., Netek, V. \& Kapoun, P. (2020). Engaging Customers on Facebook Coffee Shops' Brand-Fan Pages. International Journal of Entrepreneurial Knowledge, 8(1), 65-75.

6. Fleming, M. (2020). How McDonald's is returning marketing to a 'growth pillar'. Marketingweek. Available at: https://www.marketingweek.com/mcdonalds-marketinggrowth-pillar/

7. Gavurova, B., Bacik, R., Fedorko, R., \& Nastisin, L.(2018). The Customer's Brand Experience in the Light of Selected Performance Indicators in the Social Media Environment. Journal of Competitiveness, 10(2), 72 - 84.

8. Gorska, A., \& Mazurek, G. (2021). The effect of the CEO media coverage on corporate brand equity: evidence from Poland. Oeconomia Copernicana, 12(2), 499-523.

9. Gregova, E., Dengov, V., Tulyakova, I., \& Mustafaev, A. (2020). Private Label as a global trend of food networks for pricing policy optimization (case study of St. Petersburg). 74(3).

10. Klein, D. (2020). McDonald's is Flexing its Marketing Muscle Again. QSR. Available at: https://www.qsrmagazine.com/fast-food/mcdonalds-flexing-its-marketing-muscleagain

11. Kowitt, B. (2020). McDonald's responds to the pandemic with faster drive-thrus, loyalty points, and a new chicken sandwich. Fortune. Available at: https://fortune.com/2020/11/09/mcdonalds-covid-growth-strategy-chicken-sandwichloyality-program-drive-thru/ 
12. Kumar, S. U., Russ, H. (2020). McDonald's launches new growth strategy; beats profit estimates. Business News. Available at: https://www.reuters.com/article/us-mcdonalds-corp-results-idUSKBN27P1EM

13. Lintott, R. (2019). McDonald's innovation in the US. Analysis. VerdictFood Service. Available at: https:/www.verdictfoodservice.com/features/mcdonalds-innovation-us/

14. Macrotrends. (2021, May 25). McDonald's Financial Statements 2005-2021 | MCD. Macrotrends. Available at: https:/www.macrotrends.net/stocks/charts/ $\mathrm{MCD} / \mathrm{mcdonalds} /$ financial-statements

15. McDonald's company. (2020, November 9). McDonald's Announces New Growth Strategy. The Corporate McDonald's. Available at: https://corporate.mcdonalds.com/corpmcd/en-us/our-stories/article/press-releases.newgrowth-strategy.html

16. McDonald's company. (2021, April 29). McDonald's Announces New Growth Strategy. The Corporate McDonald's. Available at: https://corporate.mcdonalds.com/corpmcd/enus/our-stories/article/FinancialNews.Q1-2021-results.html

17. Musova, Z., Musa, H., \& Matiova, V. (2021). Environmentally responsible behaviour of consumers: Evidence from Slovakia. Economics and Sociology, 14(1), 178-198.

18. Scott, R., Poliak, M., Vrbka, J., \& Nica, E. (2020). COVID-19 Response and Recovery in Smart Sustainable City Governance and Management: Data-driven Internet of Things Systems and Machine Learning-based Analytics. Geopolitics, History, and International Relations, 12(2), $16-22$.

19. Shastri, A. (2020). Mcdonald's Marketing Case Study - I'm Lovin' It Already. IIDE. Available at: https://iide.co/case-studies/mcdonalds-marketing-strategy/

20. Stefko, R., Bacik, R., Fedorko, R., Olearova, M., \& Rigelsky, M. (2019). Analysis of consumer preferences related to the use of digital devices in the e-commerce dimension. Entrepreneurship and Sustainability Issues, 7(1), 25-33.

21. Stefko, R., Fedorko, R., Bacik, R., Rigelsky, M., \& Olearova, M. (2020). Effect of service quality assessment on perception of TOP hotels in terms of sentiment polarity in the Visegrad group countries. Oeconomia Copernicana, 11(4), 721-742

22. The One Brief. (2021, May 24). Case study: McDonalds responds to the COVID-19 crisis. The One Brief. AON. Available at: https://theonebrief.com/case-studymodonalds-responds-to-the-covid-19-crisis-nb/

23. Valaskova, K., Durana, P., \& Adamko, P. (2021). Changes in Consumers' Purchase Patterns as a Consequence of the COVID-19 Pandemic. Mathematics, 9(15), 1788.

24. Valentine, M. (2021). Marketing muscle' helps McDonald's beat pre-pandemic sales. Marketingweek. Available at: https:/www.marketingweek.com/marketing-musclemedonalds/

25. Vrbka, J., Nica, E., \& Podhorska, I. (2019). The application of Kohonen networks for identification of leaders in the trade sector in Czechia. Equilibrium. Quarterly Journal of Economics and Economic Policy, 14(4), 739 - 761.

26. Warc (2020, June 22). McDonald's plans major marketing push. Warc. Available at: https://www.warc.com/newsandopinion/news/mcdonalds-plans-major-marketingpush/43759

27. Worimegbe , P. M., Worimegbe, T. M., Abiola-Oke, E. (2020). Gamification and Customers Experience in the Hospitality Industry. Journal of Tourism and Services, 21(11), 71-87. 